INTERNATIONAL HIGHER EDUCATION Number 75 Spring 2014

Pages 22-24

\title{
Private Higher Education's Quality Assurance in Ghana
}

\section{LINDA TSEVI}

Linda Tsevi is a PhD candidate at the Department of Educational Administration and Policy Studies, University at Albany, State University of New York. E-mail: ltsevi@albany.edu.

IHE regularly publishes an article on private higher education from PROPHE, the Program for Research on Private Higher Education, headquartered at the University at Albany. See http:/ /www.albany.edu/.

Quality assurance in higher education institutions in Ghana began in the early 1990s-in response to an increase in the number of private institutions, providing postsecondary education and concern over their level of performance. As elsewhere in Africa, government felt a need to act.

Also as in much of Africa the backdrop involved a growing population's rising demand for higher education, government failure to meet it, and therefore government acquiescence in a surge of private higher education. However, the government would have met rising demand in any case. Its capacity was undermined by the economic downturn of the 1980s and pressure from the World Bank, to shift public educational expenditures to schools and thus leave the financial burden for expanding higher education more to private 
stakeholders. Ghana experienced decreased government funding for higher education in the 1990s, the full-time equivalent funding per student decreasing from US\$2,500 in 1990 to US\$900 in 1997.

This private higher education growth did not mean that government initially established a formidable public design for it. Instead, its basic posture was to permit private stakeholders to blaze the way. That would be a route to accomplish the public interest goal of rapidly expanding access. Current accredited private institutions included 3 chartered universities, 53 university colleges, 5 distance learning institutions, 12 tutorial colleges, and 11 training colleges. During the 2008-2009 academic year, these institutions enrolled approximately 25,000 of the system's 177,000 total enrollment, a 14 percent share.

\section{The Quality CONCERN}

Typical of such situations of private proliferation, government, student, and public concerns soon mounted about quality. By quality assurance, government and others generally envisioned reviews of programs and institutions that involve some systematic measuring performance against standards of academic and infrastructural matters. Whatever the concerns over general or declining quality in public higher education, the widespread view was that the public sector already had internal quality-assurance mechanisms and norms in place. Then, too, political dynamics sometimes made it uncomfortable for government to challenge entrenched public university practices and interests.

Quality assurance was envisioned on two fronts: internal and external. The internal part would make certain that a program or an institution has policies that guide its standards and objectives. On the other hand, the external 
part would be conducted by outside organizations. External quality-assurance mechanisms would include accreditation, quality audit, and quality assessment. Whatever the motivation of government, private institutions often recognized the quality-assurance process as an opportunity to establish their legitimacy.

\section{The National Accreditation Board}

In 1993, the government of Ghana enacted Provisional National Defence Council law 317 under policy guidelines to establish the National Accreditation Board, as the nation's quality-assurance body for higher education institutions. This legislation was substituted by other government acts in 2007 and 2010; these regulations constituted part of the "delayed regulation" of private higher education. Generally, the National Accreditation Board's quality assurance involves both institutional and program accreditation. Higher education institutions must meet certain minimal requirements that are verified through self-study documents prepared, followed by panel visits from that board.

A particular configuration in the Ghanaian case is that private universities begin as university colleges affiliated to public universities, which serve as mentors for a number of years. The quality-assurance rationale is to guard against proliferation of freestanding private institutions that lack the ability, will, or offer adequate quality. The application has the proposed name of the university college, academic resources available, and timetable-indicating how within the next three years the objectives of the institution are to be achieved. The premises of the new private university college are inspected, verified, and subsequently issued with a letter of interim authority. A private institution qualifies for institutional accreditation-only if among other things, it meets 
minimum admission requirements for certificate, diploma, and degree levels; minimum number of students enrolled; and minimum qualifications of faculty. Institutional charters are granted by the president of the country. A private institution qualifies for an institutional charter if it has been affiliated to a mentoring institution for at least 10 years and has fulfilled all necessary requirements.

A private institution's program qualifies for accreditation; if, among other things, it states minimum student admission requirements, description of courses, and provides rules on student performance. In addition, educational programs have to align with national education policies to qualify for accreditation.

Linked to the National Accreditation Board, quality assurance mechanisms are efforts to deal with quality based on financial integrity. In Ghana, private institutions are owned by individuals or through partnerships; they are tax exempt. However, there have been proposals to have this tax privilege withdrawn, leaving a tax-exempt status only for institutions engaged in more academic than commercial pursuits. These proposals have generated anger among the private institutions. They offer courses that require very low infrastructural and equipment investment, and their specific curriculums are tailored to the labor market. For example, they see their reliance on a faculty composed mostly of adjuncts appropriate for linking with the market; whereas critics see dependence on part-timers as evidence of limited academic quality.

Problems of the National Accreditation Board include its ability to keep pace with accredited institutions offering programs that have not been authorized. Similarly, it has to regularly monitor accredited private institutions, 
to ensure they do not admit students lacking the minimum qualifying requirements, a common occurrence at some private institutions. The board also has the challenge of monitoring private institutions and their satellite campuses that are not accredited but start advertising to the public as if they had accreditation.

\section{CONCLUSION}

Ghana's private higher education system has been impacted by policies as well as other precipitating factors in its current situation. Quality assurance in Ghana on both the institutional and program accreditation fronts is mandatory for public and private institutions. Quality assurance has indeed brought a true measure of quality to accredited institutions. The National Accreditation Board has been vigilant in monitoring private institutions. Nonetheless, it still has to be continually alert in order to protect the unsuspecting consumer. 